\title{
Treatment of Petroleum and Flowstation Wastewater Using Combined Coagulants
}

\author{
Evbuomwan, B.O Olagunju, L.A \\ Department of Chemical Engineering, University of Port Harcourt, Nigeria
}

\begin{abstract}
Performance and effectiveness of single and combined coagulants in the treatment of petroleum and flow station wastewater has been studied. In this study, samples of petroleum and flowsation were treated separated with Barium Chloride, Iron (ii) sulphate, Magnesium Oxide and then with mixtures of different chemicals. Standard methods for examination of water and wastewater was used in the analysis of some important physico-chemical parameters. The results of the analysis of all the parameters in the petroleum and flow station wastewater samples treated with six different types of coagulants shows significant changes and variations in the level of virtually all the parameters in the treated samples when compared with that of the blank. The combined chemical coagulants exhibited a high capacity to reduce the pollutants to recommended effluent limits with the mixture of Magnesium Hydroxide and Iron (ii) Sulphate been the most effective coagulants. The result revealed that average value of all selected parameters showed variation from points A to F. However, these variations are not statistically significant with F (0.068019) being less than Fcritical
\end{abstract}

Keywords: Petroleum, Flow station, Wastewater, Coagulants, ANOVA

DOI: $10.7176 / \mathrm{CPER} / 62-04$

Publication date: January $31^{\text {st }} 2020$

\section{INTRODUCTION}

One of the greatest problems faced by the oil rich Niger-Delta part of Nigeria is the lack of clean surface and underground water. This is due to the contamination of water bodies with petroleum hydrocarbon. During well drilling, petroleum production, refining and transportation, a large amount of hydrocarbon is spilled directly on the surface of water bodies. They are wastes resulting from processes employed in petroleum industrial establishments and discharged into the environment (Eletta et al, 2006). Managing oil and gas industrial environment requires close and constant monitoring of the effluent discharges from such industries. The essence of such monitoring is to ascertain the level of compliance of such industries with the pollution control guidelines set by regulatory agencies in Nigeria such as Department of Petroleum Resources and Federal Ministry of Environment.

In flow stations, wastewater consists of water dump coming out of API tank going to the pit which may have mixed with other forms of wastewater such as, produced water after separation of oil and water, sewage water, condensed steam from heaters, overboard water from water injection and drain lines. Wastewaters from petroleum exploration and production processes represent important point sources of toxic organics in the last decade. The petroleum wastewater are complex materials of organic pollutants and most of them contented oil and grease, which clog drain pipes and causing unpleasant odours ( $\mathrm{Xu}$ and $\mathrm{Zhu}, 2004$ ). In addition, petroleum and flow station waste water also contain nitrates. Petroleum and flow station wastewater effluent will vary from one company to another, depending on the degree of water reuse, and the on-site treatment methods that are used. Effluent water is often referred to as wastewater. Such water contains fundamentally some quantity of substance in such a concentration that makes the water technically polluted (Stephenson,2012). The composition of petroleum wastewater and their negative effects are summarized by Elshamy et al, 2017. The analysis used to characterized the principal impurities found in petroleum and flow station wastewater are have been reported by John Pichtel,2016.

However, in flow stations, petroleum wastewater can be sampled from the water outlet of oil-water separators, and this main produced water is majorly re-injected for flooding or disposed.(OPITO 2002) . Oil water separators can be designed to treat a variety of contaminants in water including free floating oil, emulsified oil, dissolved oil and suspended solids. Presently, physical, biological and chemical methods are the different conventional methods of petroleum and flow station wastewater treatment. Coagulation, flocculation, precipitation and electrochemical methods are the common chemical techniques and the chemical treatment depends on the type of coagulants ( Marttinen et, al, 2002). Although aluminum sulphate and ferric chloride are commonly used coagulants, its high cost have induced several investigators to search for low cost non-conventional coagulants. This paper, therefore, examined the suitability of using alternative non-conventional single or combined chemicals as coagulant for petroleum and flow station wastewater treatment. 


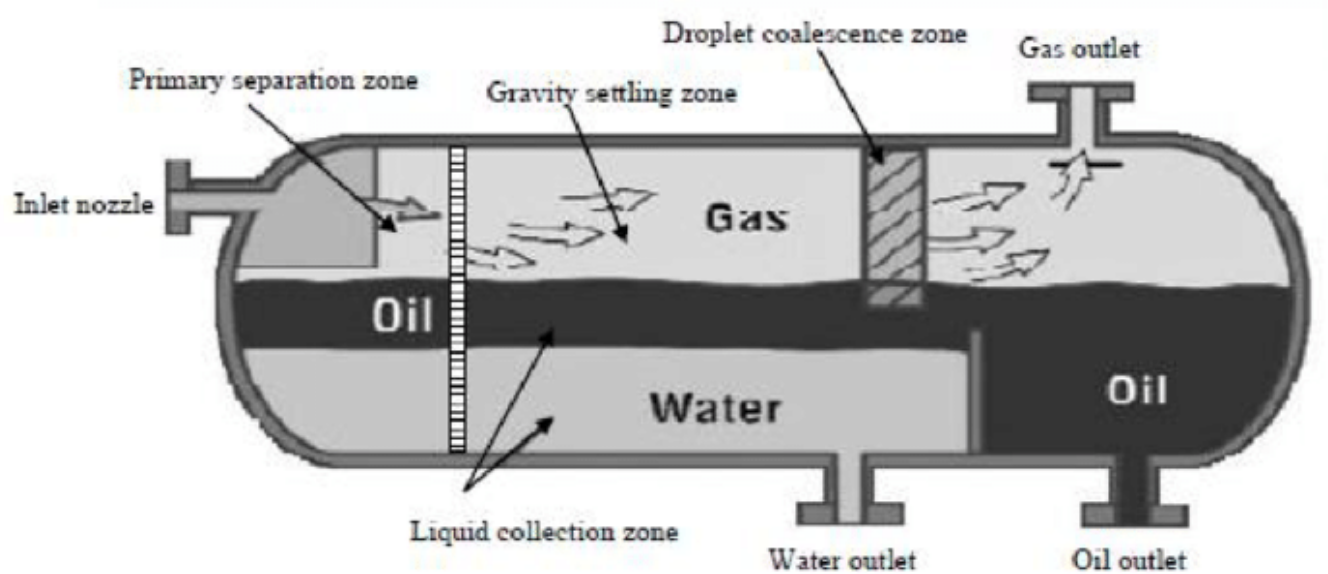

Figure 1 Three phase gravity Separator ; Source(Researchgate.net)

\section{MATERIALS AND METHODS}

The chemical coagulants employed in this research were general purpose grade Ferrous sulphate, Barium chloride and magnesium hydroxide Sample of petroleum wastewater used was collected from a flow station/production platform in a 20 litre jerry can, previously washed with thorough with potable water and dried. The jerry can was filled to the brim with the sample and allowed to overflow in order to remove the entrapped air.. The sample sealed and transported to the laboratory for analysis. Coagulation studies were performed using jar test apparatus. Ferric sulphate, Barium chloride, Magnesium chloride and mixtures of ferric sulphate and barium chloride, ferric sulphate and magnesium hydroxide and barium chloride and magnesium hydroxide were treated with the petroleum and flow station wastewater. At the end of the chemical analysis, the clear filtrate was furthered analyzed for some important parameters using Standard for the examination of water and wastewater ( Eugene, et al 2012 )

RESULTS AND DISCUSSION

Table 1: Treatment of samples with single coagulants

\begin{tabular}{|c|c|c|c|c|c|c|}
\hline Parameters & Blank & $\begin{array}{c}\mathrm{FeS0}_{4} \\
(5 \mathrm{~g} / 100 \mathrm{ml})\end{array}$ & $\begin{array}{c}\mathrm{BaCl}_{2} \\
(5 \mathrm{~g} / 100 \mathrm{ml})\end{array}$ & $\begin{array}{c}\mathrm{Mg}(\mathrm{OH})_{2} \\
(5 \mathrm{~g} / 100 \mathrm{ml})\end{array}$ & $\begin{array}{c}\text { DPR } \\
\text { Limit } \\
\text { (offshore) }\end{array}$ & $\begin{array}{l}\text { FMENV } \\
\text { Limits }\end{array}$ \\
\hline $\mathrm{pH}$ & 5.8 & 6.8 & 7.1 & 9.8 & $6.5-8.5$ & $6.5-8.5$ \\
\hline $\mathrm{BOD}(\mathrm{mg} / \mathrm{l})$ & 759.17 & 5.82 & 13.12 & 0.68 & - & - \\
\hline COD (mg/l) & 929.88 & 8.26 & 14.68 & 2.83 & - & - \\
\hline TSS (mg/l) & 284 & 212 & 132 & 156 & 50.0 & 30.0 \\
\hline $\mathrm{O} \& \mathrm{G}(\mathrm{mg} / \mathrm{l})$ & 4124 & 6.27 & 14.13 & 0.73 & 40.0 & 10.0 \\
\hline $\begin{array}{l}\text { Electrical Conductivity } \\
(\text { microohms } / \mathrm{cm})\end{array}$ & 22300 & 21300 & 32500 & 22000 & - & - \\
\hline TDS (mg/l) & 12600 & 12035 & 18363 & 12430 & 5000 & 2000 \\
\hline Alkalinity $(\mathrm{mg} / \mathrm{l})$ & 1624 & 300 & 1052 & 5012 & - & - \\
\hline $\begin{array}{l}\text { Total Organic Carbon } \\
(\mathrm{TOC})(\mathrm{mg} / \mathrm{l})\end{array}$ & 1229 & 2.31 & 5.21 & 0.27 & - & - \\
\hline Chlorides $\mathrm{Cl}^{-}$ & 9954 & 9508 & 14507 & 9820 & - & - \\
\hline
\end{tabular}


Table 2:Treatment of Samples with combined coagulants

\begin{tabular}{|c|c|c|c|c|c|c|}
\hline Parameters & Blank & $\begin{array}{c}\mathrm{FeS0}_{4} \\
\text { and } \\
\mathrm{BaCl}_{2} \\
(5 \mathrm{~g} / 100 \mathrm{ml})\end{array}$ & $\begin{array}{c}\mathrm{FeS0}_{4} \\
\text { and } \\
\mathrm{Mg}(\mathrm{OH})_{2} \\
(5 \mathrm{~g} / 100 \mathrm{ml})\end{array}$ & $\begin{array}{c}\mathrm{BaCl}_{2} \\
\text { and } \\
\mathrm{Mg}(\mathrm{OH})_{2} \\
(5 \mathrm{~g} / 100 \\
\mathrm{ml} \\
\end{array}$ & $\begin{array}{c}\text { DPR } \\
\text { Limit } \\
\text { (offshore) }\end{array}$ & $\begin{array}{l}\text { FMENV } \\
\text { Limits }\end{array}$ \\
\hline $\mathrm{pH}$ & 5.8 & 7.8 & 6.3 & 8.3 & $6.5-8.5$ & $6.5-8.5$ \\
\hline $\mathrm{BOD}(\mathrm{mg} / \mathrm{l})$ & 759.17 & 12.47 & 1.19 & 1.69 & - & - \\
\hline $\mathrm{COD}(\mathrm{mg} / \mathrm{l})$ & 929.88 & 11.97 & 4.95 & 7.04 & - & - \\
\hline $\mathrm{TSS}(\mathrm{mg} / \mathrm{l})$ & 284 & 103 & 160 & 16 & 50.0 & 30.0 \\
\hline $\mathrm{O} \& \mathrm{G}(\mathrm{mg} / \mathrm{l})$ & 4124 & 13.43 & 1.28 & 1.82 & 40.0 & 10.0 \\
\hline $\begin{array}{l}\text { Electrical Conductivity } \\
\text { (microohms/cm) }\end{array}$ & 22300 & 21100 & 22200 & 26500 & - & - \\
\hline TDS (mg/l) & 12600 & 11922 & 12543 & 14973 & 5000 & 2000 \\
\hline Alkalinity $(\mathrm{mg} / \mathrm{l})$ & 1624 & 740 & 8020 & 2460 & - & - \\
\hline $\begin{array}{l}\text { Total Organic Carbon } \\
(\mathrm{TOC})(\mathrm{mg} / \mathrm{l})\end{array}$ & 1229 & 4.96 & 0.47 & 0.67 & - & - \\
\hline Chlorides $\mathrm{Cl}^{-}$ & 9954 & 9418 & 9909 & 11829 & - & - \\
\hline
\end{tabular}

ANALYSIS OF VARIANCE (ANOVA)

Due to the wide variation in the values of the parameters obtained from the analysis of the treated samples, it becomes necessary to subject the data to statistical analysis of variance to further proof the observed variation statistically. The one-way analysis of variance (ANOVA) was used to determine whether there are any statistically significant differences between the means of the six independent (unrelated) groups.

Table 3: Summary of single and combined values of parameters

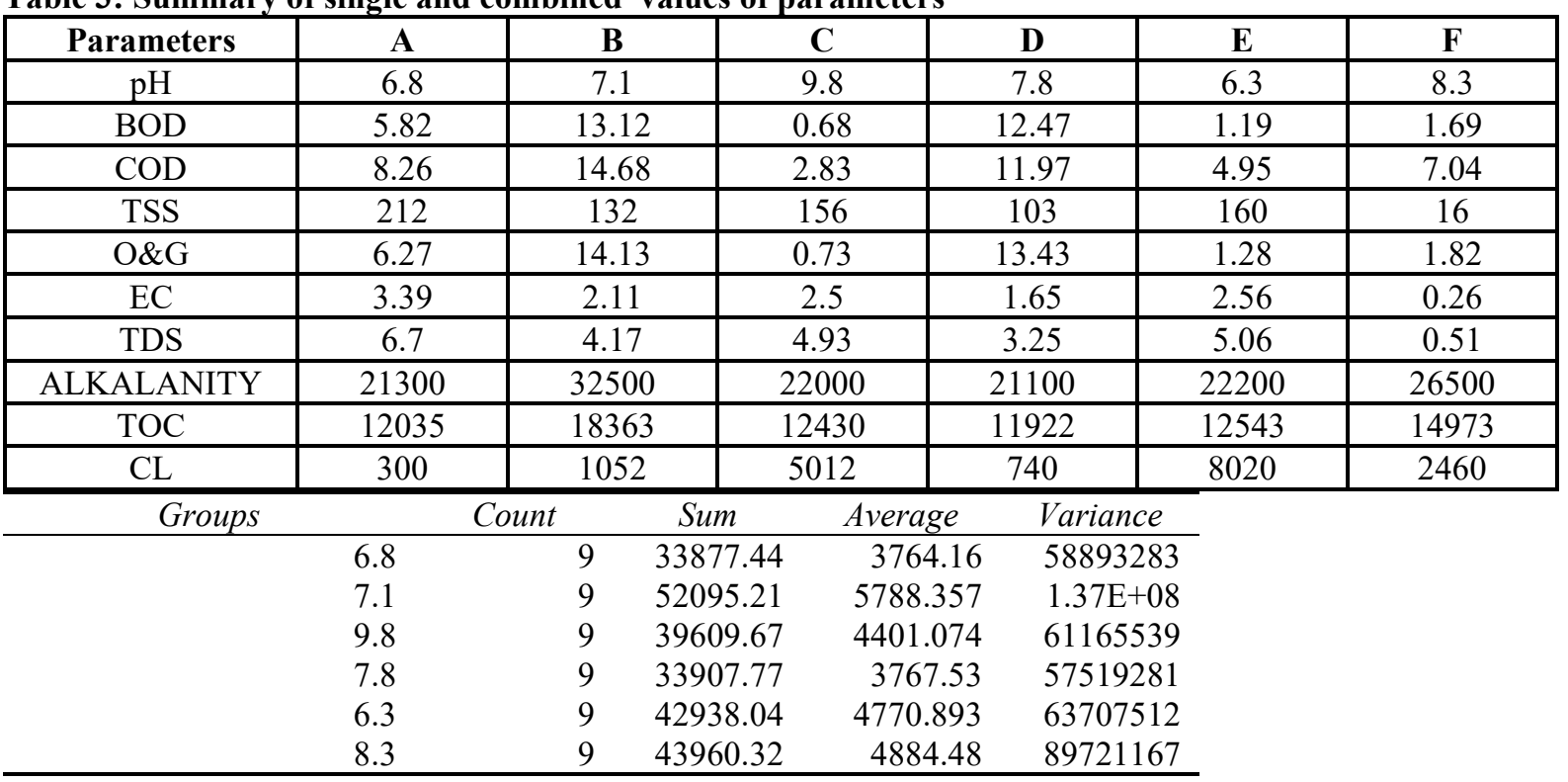

\begin{tabular}{lcrrrrc}
\hline ANOVA & \multicolumn{1}{c}{} & & \\
\hline \multicolumn{1}{c}{ Source of Variation } & $S S$ & $d f$ & \multicolumn{1}{c}{$M S$} & \multicolumn{1}{c}{ P } & P-value & F crit \\
\hline Between Groups & 26506848 & 5 & 5301370 & 0.068019 & 0.99661 & 2.408514 \\
Within Groups & $3.74 \mathrm{E}+09$ & 48 & 77939231 & & & \\
Total & $3.77 \mathrm{E}+09$ & 53 & & & & \\
\hline
\end{tabular}

Where $\mathrm{A}=$ Ferric Sulphate $\left(\mathrm{FeSO}_{4}\right), B=$ Barium Chloride $, \mathrm{C}=\mathrm{Mg}(\mathrm{OH})_{2}, \mathrm{D}-$ Ferric Sulphate / Barium Chloride $\quad, \quad E=$ Ferric Sulphate /Magnesium Hydroxide and $F=$ Barium Chloride / Magnesium Hydroxide

The results of the analysis of all the parameters in the petroleum wastewater samples treated with six different types of coagulants are shown in tables 1 and 2 . The results shows significant changes and variations in the level of virtually all the parameters in the treated samples when compared with that of the blank.

The determination of Oil and Grease presence in water is very important and necessary as a measure of oil carry over in the petroleum industry and production platforms. Increased or high presence of Oil and Grease in 
water is dangerous to aquatic life's. From the results obtained, all the chemicals proved effective and the percentage removal of oil and grease was very high, thereby meeting the regulatory standard.

Total Dissolved Solids (TDS) are the combination of all the organic and inorganic substances contained in the water, they are present in iodized molecular or micro-granular form. In table 1 above, there Is no significant reduction in the values of TDS of the treated samples when compared with the blank with $12,600 \mathrm{mg} / 1$, increase is rather noted in the case of Barium Chloride $\left(\mathrm{BaCl}_{2}\right)(18363 \mathrm{mg} / \mathrm{l})$ and mixture of Barium Chloride $\left(\mathrm{BaCl}_{2}\right)$ and Magnesium Hydroxide $\mathrm{Mg}(\mathrm{OH})_{2}$ with an increased TDS of 14973 . This could be as a result of presence of Chloride in those chemicals which subsequently forms more dissolved salts in the solution.

Total suspended solids(TSS) are solids that cannot pass through the pores of a sieve or filter paper of 2 micrometers and yet are indefinitely suspended in the water. High value of TSS will affect the aquatic organisms because this can influence the level of dissolved oxygen in the water.

The results from the table above implies that only the mixture of Barium Chloride $\left(\mathrm{BaCl}_{2}\right)$ and Magnesium Hydroxide $\mathrm{Mg}(\mathrm{OH})_{2}$ was able to reduce the total suspended solids significantly to meet the required standard, this chemical mixture reduced the total suspended solids from $284 \mathrm{mg} / 1$ to $16 \mathrm{mg} / 1,94.4 \%$ removal.

There was increase in $\mathrm{pH}$ values for all the samples for Ferrous Sulphate, Barium Chloride, Magnesium hydroxide, Ferrous Sulphate with Barium Chloride, Ferrous Sulphate with Magnesium Hydroxide and Barium Chloride with Magnesium Hydroxide.

The alkalinity of water is its acid neutralizing capacity. It is the sum of the titratable bases using a standard acid. The results showed that the neutralizing capacity of each of the coagulants is highly dependent on the power of the cation present in each of the chemicals. The blank alkalinity of $1624 \mathrm{mg} / \mathrm{l}$ dropped to $300 \mathrm{mg} / \mathrm{l}$ after treatment with Ferric Sulphate, this is $82 \%$ reduction in the acid neutralizing power of the original sample, an indication of the presence of a weak cation and a strong anion in the composition of the coagulant.

Furthermore, the reverse was the case for Magnesium Hydroxide and the mixture of Ferric Sulphate and Magnesium Hydroxide, these produced good examples of more alkaline solutions as they increased the alkalinity from $1624 \mathrm{mg} / 1$ to $5012 \mathrm{mg} / 1$ and $8020 \mathrm{mg} / 1$, respectively.

For conductivity test, $\mathrm{BaCl}_{2}$ seems to be highly conductive as its presence in the solution significantly increased the conductivity compared to other coagulants. For the treated samples with Barium chloride and mixture of Barium chloride with Magnesium Hydroxide, the conductivity increased from $22300 \mathrm{microohms} / \mathrm{cm}$ for the blank to $32500 \mathrm{microohms} / \mathrm{cm}$ and $26500 \mathrm{microohms} / \mathrm{cm}$ respectively, while those of other samples falls in the same range with the blank with slight differences.

Another parameter worthy to be noted and whose determination is very important is the chemical oxygen demand(COD), it is a measure of the capacity of water to consume oxygen during the decomposition of organic matter and the oxidation of inorganic chemicals such as Ammonia and nitrite. From the result, there is significant reduction in the COD values of all the analyzed treated when compared the blank. The blank COD value of 929.88 $\mathrm{mg} / \mathrm{l}$ was reduced to $8.26 \mathrm{mg} / \mathrm{l}$ by Ferrous Sulfate, $14.68 \mathrm{mg} / \mathrm{l}$ by Barium Chloride,2.83mg/l by Magnesium Hydroxide, $11.97 \mathrm{mg} / \mathrm{l}$ by the mixture of Ferrous Sulfate and Magnesium Hydroxide, $4.95 \mathrm{mg} / \mathrm{l}$ by the mixture of Ferrous Sulfate and Magnesium Hydroxide and also reduced to $7.04 \mathrm{mg} / \mathrm{l}$ by the mixture of Barium Chloride and Magnesium Hydroxide, Magnesium Hydroxide proved most effective in this area.

For the total organic Carbon (TOC) removal, all the coagulants showed very high effectiveness especially by Magnesium Hydroxide, mixture of Ferrous Sulfate and Magnesium Hydroxide and Barium Chloride with Magnesium Hydroxide, these three chemicals reduced the TOC from $1229 \mathrm{mg} / 1$ to $0.27 \mathrm{mg} / 1,0.47 \mathrm{mg} / 1 \mathrm{and} 0.67 \mathrm{mg} / 1$ respectively.

For the Chloride ions, the removals by non-chloride Coagulants are very insignificant while the coagulants that contain chloride in them only increased the chloride ions present in the sample. This can be seen in the samples treated with Barium Chloride and the mixture of Barium Chloride with Magnesium Hydroxide, these two coagulants rather increased the Chloride ions from a blank value of $9954 \mathrm{mg} / 1$ to $14507 \mathrm{mg} / \mathrm{l}$ and $11829 \mathrm{mg} / 1$ respectively.

One way ANOVA and correlation was employed to see the statistical difference of the variables at $5 \%$ significant level and to observe associations of variables. The result revealed that average value of all selected parameters showed variation from points A to F. However, these variations are not statistically significant with F (0.068019) being less than $\mathrm{F}_{\text {critical }}(2.408514)$.

\section{CONCLUSION}

This research shows that combination of chemicals can have high efficiency in the treatment of petroleum and flow station wastewater. The chemical coagulants exhibited a high capacity to reduce the pollutants to recommended effluent limits with the mixture of Magnesium Hydroxide and Iron (ii) Sulphate been the most effective coagulants. 


\section{REFERENCES}

1. Stephenson R, Tennant B (2002) New Electro coagulation Process Treats Emulsified Oily Wastewater at Vancouver Shipyards. Environ Sci Eng Mag.

2. El-shamy AM,Hanaa A. El-baraey, El-Awdan HF (2017) Chemical Treatment of Petroleum Wastewater and its effect on the corrosion behaviour steel pipeline in Sewage Network. J Chemical Engineering Process Technology 8: 324.

3. http://www.globalspec.com/reference/46928/203279/chapter-5-three-phase-oil-and-water-separation

4. Pitchel J. (2016). Oil and Gas Production Wastewater, Soil Contamination and Pollution Prevention. Applied and Environmental Soil Science, pp 1-24.

5. OPITO (Offshore Petroleum Industry Training Organization, UK)(2002),Produced Water Treatment, part of the Petroleum Processing Technology Series, Petroleum Open Learning.

6. FEPA (1991):- Federal Environmental Protection Agency, Guidelines and Standards for Environmental Pollution in Nigeria, 1991.

7. $\mathrm{Xu}, \mathrm{X}$ and $\mathrm{Zhu}, \mathrm{X}$ (2004): Treatment of refractory oily wastewater by electro-coagulation process. Chemosphere, 56,889-894

8. Marttinen, S.K, Kettunen, R.H, Somunen, K.M, Soimasuo, R.M, Rintala, J.A(2002): Screening of physicalchemical methods for removal of organic material, nitrogen and toxicity from low strength landfill leachates, Chemosphere, 46: 851-858

9. Eugene, W.R, Rodger B, Andrew, D.E, Lenore, S.C, Laura, B(2012): Standard methods for the examination of water and wastewater, $22^{\text {nd }}$ ed, Washington, D.C. American Public Health Association. 